\title{
EVALUATION OF USAGE OF DISCRETE EVENT SIMULATION AS THE TOOL OF MANAGERIAL DECISION MAKING SUPPORT IN MANUFACTURING ENTERPRISE
}

\author{
[Hodnocení použití diskrétní simulace jako nástroje pro podporu manažerského \\ rozhodování ve výrobním podniku]
}

\author{
Tomáš Šupina ${ }^{1}$, Marie Jurová ${ }^{2}, J$ an Holubík ${ }^{3}$ \\ ${ }^{1}$ Vysoké učení technické v Brně, Podnikatelská fakulta, Kolejní 2906/4, 61200 Brno \\ Email: supina@fbm.vutbr.cz. \\ ${ }^{2}$ Vysoké učení technické v Brně, Podnikatelská fakulta, Kolejní 2906/4, 61200 Brno \\ Email: jurova@fbm.vutbr.cz \\ 3 Vysoké učení technické v Brně, Podnikatelská fakulta, Kolejní 2906/4, 61200 Brno \\ Email: holubik@fbm.vutbr.cz
}

\begin{abstract}
Discrete event simulation is a modern tool for analyzing complex manufacturing, supply, communication and other business processes. This article aims to describe the difference in the perception of the benefits of simulation between a business that uses this tool and a business where this tool is not available for managers. Conclusion of this article expresses the level of benefit from using simulation in these positions, eg in relation to the project budget, flexibility to changes, etc., in context of managerial functions according to Fayol.
\end{abstract}

Keywords: data, decision-making, discrete event simulation, management.

JEL classification: M11

Doručeno redakci: 23.2.2014; Recenzováno: 19.5.2014; 10.6.2014; Schváleno k publikování: 11.2.2015

\section{Úvod}

Organizace jsou velmi složité jednotky, propletené sítě rozličných individualit, firemních kultur, struktur, systémů, technologií a procesů (McLean, 2011). Každodenně čelí stovkám komplexních rozhodování, např. jak uspořádat výrobní linku, jestli expandovat na další trh a jsou-li dostupné kapacity pro expanzi, jestli naopak omezit výrobu atd. Jak ale poznamenává Mitroff (2008), není již na denním pořádku, aby se pozastavily nad otázkou, zda metody, které používají pro podporu svých rozhodování, jsou vhodné pro daný typ problému, př́padně zda neexistují jiné, lepší.

V posledních několika desetiletích se aplikace počítačové simulace pro manipulační komplexní inženýrské systémy jeví jako velmi slibná metoda, zaměření článku se proto týká vnímání př́ínosů diskrétní simulace pro výrobní podniky.

\section{Literární přehled}

Rozhodování patří mezi jedny z nejvýznamnějších aktivit, které manažeři v organizacích realizují (Fotr, 2006). Stále více přibývá ve firmách pozic, jež mají v základu názvu právě management. Jak ale již bylo zmíněno, organizace jsou velmi složité jednotky a je pravděpodobné, že požadavky na efektivní řízení (management) stále porostou. Management (z anglického to manage = zařídit, aby věci fungovaly) označuje Mohelská (2012) za proces ovlivňování činností lidí prováděných v určité organizaci, jehož smysl tkví v zajištění 
účelného a efektivního provedení těchto činností jejich nositeli se zdroji pro tento účel přidělenými.

Aby mohl manažer provádět toto účelné a efektivní řízení, musí pro to mít celou řadu předpokladů a schopností, popsaných v mnoha odborných publikacích. Kromě schopností a předpokladů můžeme rozlišit také základní povinnosti manažerů. Ačkoli přišel Henri Fayol se svou teorií před bezmála jedním stoletím, jeho definice managementu zůstává stále jednou z nejcitovanějších v moderní době (McLean, 2011). Podstatou jeho teorie je její aplikovatelnost a obecná použitelnost $\mathrm{v}$ celé řadě manažerských a organizačních kontextů (Rees and Porter, 2008).

Henri Fayol rozlišuje manažerské povinnosti na pět základních funkcí (Rausch, 2005):

1. Plánování,

2. organizování,

3. velení (dnes časteji uváděno jako přikazování, vedení či motivace),

4. koordinace a

5. kontrola.

Plánování zahrnuje stanovování cílů, stanovování postupů a rozhodování o tom, kdo bude participovat na dílčích rozhodnutích či plánování. Nevyhnutelné jsou analýzy budoucího vývoje a tvorba plánů.

Do organizování spadá kromě stanovování cílů a stanovování postupů také definování organizačních jednotek, delegování pravomocí či výběr členů týmu pro jednotlivé projekty. Zjednodušeně zahrnuje zajišt'ování organizace odpovídajícími lidskými, kapitálovými a materiálními zdroji.

Původní Fayolův výraz „velení (commanding) nahrazují Hill a McShane (2008), slůvkem „vedení“ (leadership), čímž zdůrazňují, že se jedná o řízení, ovlivňování a motivování jednotlivců. Do této oblasti spadá mimo jiné delegování pravomocí, výběr členů pro projekty a také jakési zaopatření zaměstnanců zahrnující používání různých druhů odměn.

Koordinaci lze výstižně přeložit do slovníku současného managementu jako snahu o dosažení synergického efektu mezi všemi aktivitami v organizaci a symbiózy mezi jejich funkcemi a procesy.

Poslední funkcí manažera při tomto rozdělení je poskytování zpětné vazby a neustálá tvorba vhodného prostředí pro učení/zdokonalování, které lze zahrnout pod pojem kontrola (McLean, 2011; McShane and Hickson, 2007; Rausch, 2005).

Ne vždy je možné říci, že manažer používá ty nejlepší metody pro podporu rozhodování při řešení daného problému. Jedna ze zásadních otázek podle Mitroffa (2008) tedy zní: „Jak se máme rozhodnout, které metody $\mathrm{v}$ jakém prŕípadě použít, abychom byli schopni dělat klíčová rozhodnutí?"“

Metodou (z řeckého mé todos = touto cestou) můžeme obecně označit postup získávání poznatků o určité reálné skutečnosti. Zahrnuje soubor požadavků a principů, které přitom musí být respektovány a vymezuje způsob účelného jednání při výkonu určité činnosti, směřující k dosažení zvoleného cíle. (Mohelská, 2012).

Vhodným a oběma autorům dobře známým postupem pro získávání poznatků o určité reálné skutečnosti a pro možnost predikce budoucího vývoje je tvorba simulačních modelů a experimentování s nimi.

Simulační modely slouží obvykle k porozumění, jak se systémy chovají v průběhu času a porovnávají jejich vývoj při různých podmínkách (Sweetser, 1999). V simulačních modelech jsou subjekty reprezentovány individuálně, každá jednotlivá entita má přiděleny své specifické atributy, které determinují, co se s nimi bude dít v průběhu simulačního běhu (Tako, Robinson, 2011). Simulace je založena na předpokladu, že jakmile je model jednou řádně validován, můžeme jej použít jako podporu pro zodpovězení řady složitých otázek o komplexních systémech a zkoumání takových modelů může výrazně zlepšit naše 
porozumění chování modelovaného systému (Wohlgemuth a kol., 2006). U řady vytvořených modelů je tak možné využití i v dalších projektech, pro které původně modelovány nebyly. Modely jsou obvykle stochastické povahy, kde náhodnost je generována pomocí statistického rozdělení (Tako, Robinson, 2011). Více než 60 let používání simulací v prostředí výroby a obchodu vedlo $\mathrm{k}$ širokému spektru úspěšné aplikace v různých oblastech od designu, přes plánování a kontrolu, tvorbu strategie, až po alokaci zdrojů (Jahangerian a kol., 2010). Při použití počítačových simulací může být zahrnuto velké množství proměnných, které umožňují velmi výrazné přiblížení se skutečnosti. Jak uvádí Skoogh a kol. (2012), neustále se zvyšující požadavky na konkurenceschopnost a potřeba redukovat náklady a dodací lhůty nadále vedou ke stále širšímu využívání simulací.

\section{Použitá metodologie}

$\mathrm{V}$ rámci kvalitativního výzkumu je $\mathrm{v}$ článku použita metoda př́ípadové studie zaměřená na hodnocení přínosu použití diskrétních simulací jako nástroje pro manažerské rozhodování ve středně velkých firmách Jihomoravského kraje. Př́ípadovou studii definuje Hendl (2008) jako detailní studium jednoho nebo několika př́ípadů. Oproti statistickému šetření, kde je sbíráno relativně omezené množství dat od mnoha jedinců, je v př́padové studii shromažd'ováno velké množství dat od jednoho či několika jedinců. V př́padové studii se jedná o zachycení složitosti př́ípadu, o popis vztahů v jejich celistvosti. Předpokládá se, že důkladným prozkoumáním jednoho př́padu je možné lépe porozumět jiným podobným př́ípadům. Podle Procházkové (2008) zastánci metodiky př́ípadové studie poukazují na fakt, že pomocí ní lze často získat detailnější informace o řešení určitého problému v určitém kontextu, než u statistických metod. Na druhé straně je však třeba brát v úvahu i kritiku, která poukazuje na to, že výsledky př́padové studie je velmi obtížné zevšeobecnit.

Pro účely práce byl zvolen jeden z pěti typů př́ípadové studie podle Hendla (2008), konkrétně studie organizací a institucí. Pro tento typ př́padové studie je typické zkoumání podniků, škol, organizací, procesů apod. Mohou být stanoveny různé cíle, jako napřr. zavedení určitého typu řízení, hledání nejlepšího vzorce chování či evaluace (Hendl, 2008).

Případová studie je zaměřena na poznání podniku, konkrétně jeho vztahu a vnímání diskrétní simulace jako nástroje pro podporu rozhodování.

Základní soubor je tvořen podniky zpracovatelského průmyslu střední velikosti se zaměřením na strojírenskou výrobu se stupněm zpracování druhovýroba v Jihomoravském kraji.

Výběrovým souborem jsou dva střední podniky v Jihomoravském kraji, jeden dlouhodobě využívající simulace pro podporu rozhodování, druhý nevyužívající simulačních nástrojů.

Strukturovaný rozhovor je podle Procházkové (2008) v př́padech komplexní případové studie využívaný ke sběru dat. Otázky jsou předem připravené, s vysokou mírou detailnosti. Jednotlivé oblasti v řízení projektů určené pro hodnocení byly vybrány na základě rozhovorů s výrobními manažery při exkurzích a spolupráci s podniky. Data od těchto podniků byla získávána pomocí částečně strukturovaného rozhovoru.

Po stanovení konkrétních oblastí rízení projektů byla sesbírána a vyhodnocena data od dvou zkoumaných podniků.

Výzkum pomocí př́padové studie se skládá z několika vzájemně úzce souvisejících kroků:

1. Určení výzkumných otázek. Zvolili jsme si rozdělení manažerských funkcí podle Fayola a základní oblasti vztahující se k řízení projektu. Průběh celého kvalitativního výzkumu je determinován jejich vzájemnou interakcí.

2. Výběr př́ípadu, určení metod sběru a analýzy dat. V této fázi jsme stanovili výzkumný př́ípad a techniku sběru dat, a to strukturovaný rozhovor. Jak uvádí Hendl (2008), při práci s více různými případy je nutné zabývat se každým př́padem samostatně.

3. Př́íprava sběru dat. Jelikož je v prŕípadové studii generováno poměrně velké množství dat, je třeba připravit vhodnou databázi. 
4. Sběr dat. Sběr dat jsme realizovali formou částečně strukturovaných rozhovorů s projektovými manažery firem.

5. Analýza a interpretace dat. $\mathrm{V}$ této fázi jsme porovnávali data mezi sebou a vyvozovali závěry z jejich podobnosti či naopak odlišnosti. Tato fáze se prolíná se sběrem dat.

6. Př́prava zprávy. Cílem je přiblížit a popsat př́ípad v jeho komplexnosti a umožnit kritické posouzení průběhu studie (Hendl, 2008). Při zpracování byla využita grafická vizualizace zjištěných výsledků

\section{Analyzovaná data a výsledky výzkumu}

V souvislosti se zmiňovanou otázkou Mitroffa (2008): „Jak se máme rozhodnout, které metody použít?“, byl zvolen přístup opačný, čili vybrat jednu konkrétní metodu a u té zkoumat, jak její př́nos vnímá manažer, který má možnost s ní v podniku pracovat, a jak manažer, který jí doposud využít nemohl. Obojí v kontextu výše zmiňovaného Fayolova rozdělení. Jinak řečeno tedy zkoumat, jak praktická znalost/neznalost dané metody ovlivňuje manažerův úsudek o jejím př́nosu pro řešení konkrétního problému.

V návaznosti na informace získané částečně strukturovanými rozhovory s manažery z přibližně dvaceti různých podniků byl sestaven seznam deseti oblastí v řízení výrobních projektů, které mají pro manažery z hlediska úspěšnosti projektu velký význam. Tyto získané oblasti tvoří horní část vyhodnocovací tabulky. Levá strana tabulky zachycuje jednotlivé manažerské funkce podle Henriho Fayola.

Po sestavení vhodné vyhodnocovací tabulky byly vybrány dvě konkrétní firmy, přičemž jedna diskrétní simulace pro podporu rozhodování využívá, druhá nikoli. V obou případech se jedná o podniky střední velikosti se sídlem v Jihomoravském kraji.

Pomocí částečně strukturovaných rozhovorů byl postupně získán dostatek informací od projektových manažerů obou společností, díky nimž bylo možné vyplnit vyhodnocovací tabulky. Každou kombinaci manažerské funkce a oblasti řízení projektu je možné ohodnotit jedním z pěti stupňů na škále od žádného po největší př́inos. Interpretace hodnoty pak spočívá v hodnocení přínosu použití diskrétní simulace pro danou oblast řízení projektů.

Tabulka 1: Vyhodnocení podnikem používajícím simulace

\begin{tabular}{|c|c|c|c|c|c|c|c|c|c|c|c|c|}
\hline $\begin{array}{l}\text { Oblasti řízení } \\
\text { projektů }\end{array}$ & 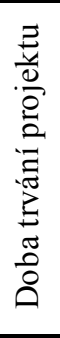 & 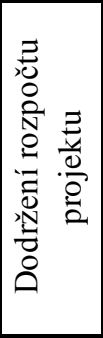 & 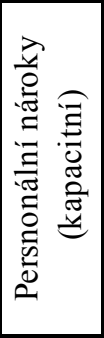 & 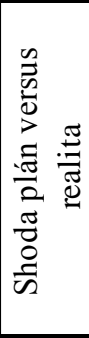 & 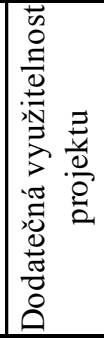 & 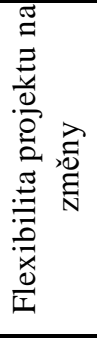 & 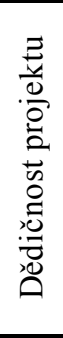 & 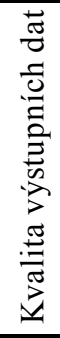 & 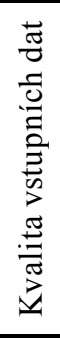 & 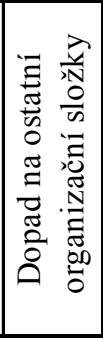 & 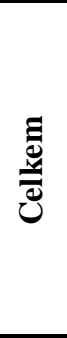 & 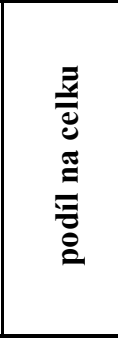 \\
\hline Plánování & 3 & 4 & 2 & 3 & 3 & 1 & 3 & 3 & 3 & 3 & 28 & $30,11 \%$ \\
\hline Organizování & 2 & 2 & 3 & 3 & 2 & 2 & 2 & 2 & 2 & 1 & 21 & $22,58 \%$ \\
\hline Přikazování & 2 & 2 & 2 & 1 & 1 & 2 & 2 & 3 & 0 & 1 & 16 & $17,20 \%$ \\
\hline Koordinace & 2 & 1 & 2 & 1 & 1 & 3 & 1 & 2 & 0 & 4 & 17 & $18,28 \%$ \\
\hline Kontrola & 1 & 1 & 0 & 2 & 2 & 1 & 0 & 3 & 1 & 0 & 11 & $11,83 \%$ \\
\hline
\end{tabular}

Zdroj: vlastní zpracování 
Tabulka 2: Vyhodnocení podnikem nepoužívajícím simulace

\begin{tabular}{|c|c|c|c|c|c|c|c|c|c|c|c|c|}
\hline $\begin{array}{l}\text { Oblasti řízení } \\
\text { projektů }\end{array}$ & 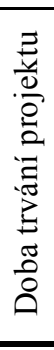 & 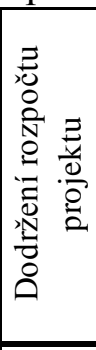 & 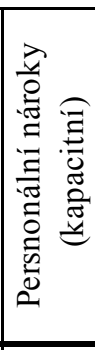 & 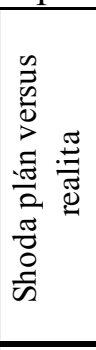 & 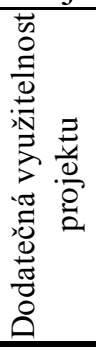 & 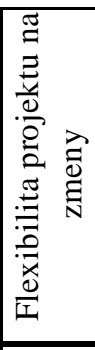 & 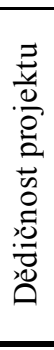 & 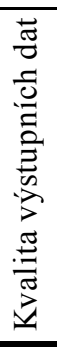 & 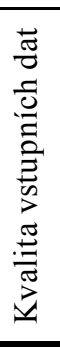 & 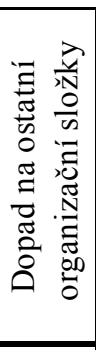 & 迅 & 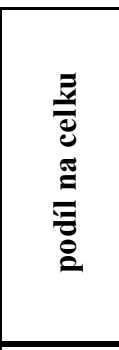 \\
\hline Plánování & 3 & 3 & 2 & 3 & 2 & 2 & 1 & 3 & 2 & 2 & 23 & $28,40 \%$ \\
\hline Organizování & 3 & 3 & 3 & 2 & 1 & 2 & 1 & 2 & 1 & 2 & 20 & $24,69 \%$ \\
\hline Přikazování & 2 & 1 & 2 & 0 & 0 & 2 & 1 & 2 & 1 & 2 & 13 & $16,05 \%$ \\
\hline Koordinace & 2 & 2 & 2 & 0 & 1 & 2 & 1 & 1 & 0 & 2 & 13 & $16,05 \%$ \\
\hline Kontrola & 2 & 1 & 1 & 1 & 2 & 1 & 0 & 1 & 0 & 3 & 12 & $14,81 \%$ \\
\hline
\end{tabular}

Zdroj: vlastní zpracování

Jak je možné vidět na Obrázku 1, procentuální rozložení přínosu diskrétních simulací pro jednotlivé manažerské funkce v kontextu všech deseti zkoumaných oblastí řízení můžeme označit za podobné, liší se poměrně minimálně. Největší část v obou prrípadech připadá na plánování ( $28 \%$ a $30 \%)$, naopak nejmenší na kontrolu (12\% a $15 \%)$. V př́ípadě kontroly se také výsledky nejvíce rozcházejí.

Obrázek 1: Srovnání výsledků - celek

Rozložení s využitím simulace

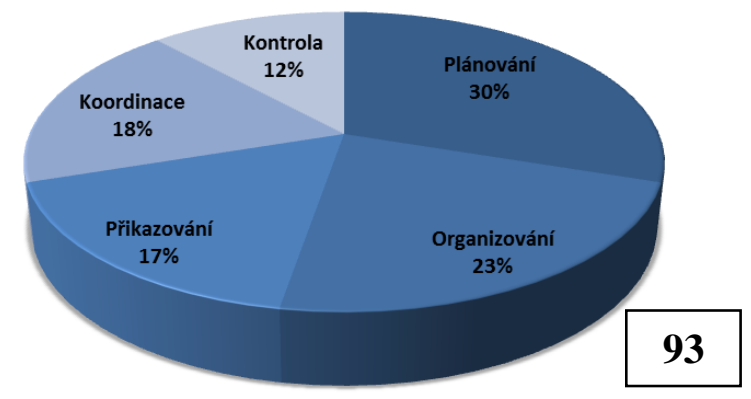

Rozložení bez využití simulace

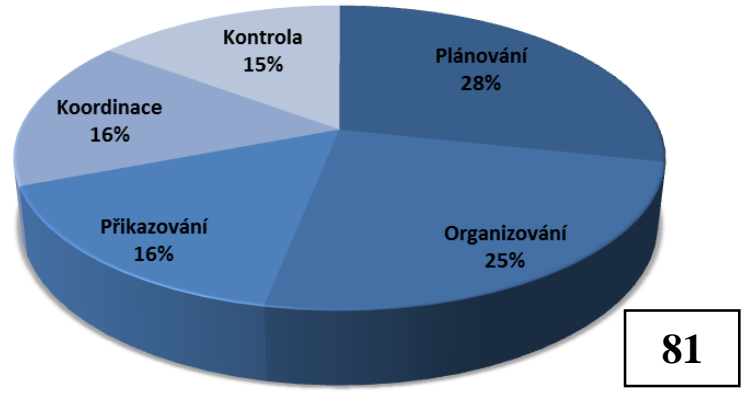

93 - celkový počet bodů

Zdroj: vlastní zpracování

Co je však důležité, je celkový součet přiřazených bodů. Zde se již výsledky liší. Zatímco manažer, který simulace reálně používá, hodnotí jejich př́ínos celkem 93 body, manažer, který diskrétní simulace v rozhodování nepoužívá, hodnotí jejich možný přínos ,pouze“ 81 body. Z toho lze usuzovat, že potenciál diskrétních simulací pro podporu manažerského rozhodování je vyšší, než manažer bez zkušeností s nimi očekává.

Zajímavý je pohled na srovnání výsledků v jednotlivých funkcích podle Fayola. Pro každý př́pad je uveden samostatný graf, kde je možné porovnat odpovědi obou manažerů zvlášt' pro každou oblast. 
Obrázek 2: Srovnání výsledků - plánování

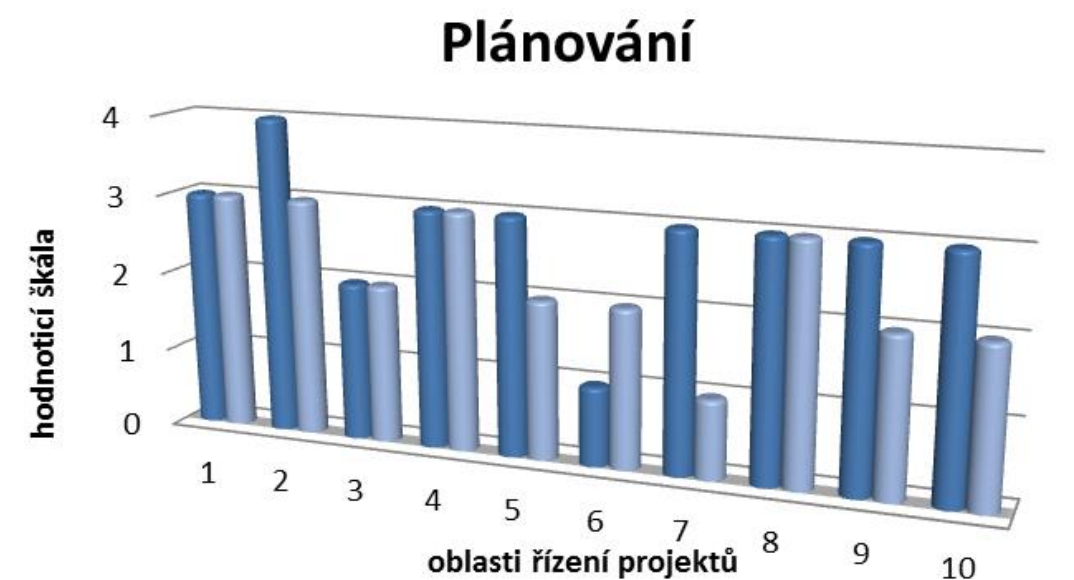

\section{Oblasti řizení výroby}

1- Doba trvání projektu

2- Dodržení rozpočtu projektu

3- Personální nároky

4- Shoda plán versus realita

5- Dodatečná využitelnost projektu

6- Flexibilita projektu na změny

7- Dědičnost projektu

8- Kvalita výstupních dat

9- Kvalita vstupních dat

10- Dopad na ostatní organizační složky

\section{$\square$ s využitím simulace $\square$ bez využití simulace}

Zdroj: vlastní zpracování

V plánování je velmi zajímavý zejména sedmý bod, tedy dědičnost projektu, kde se odpovědi výrazně rozcházejí. Tento rozdíl je dán pravděpodobně možností dobře vytvořený model použít v podobných př́ípadech znovu. Manažer využívající simulace tuto skutečnost velmi dobře zná, proto přikládá mnohem vyšší hodnotu.

Obrázek 3: Srovnání výsledků - organizování

\section{Organizování}

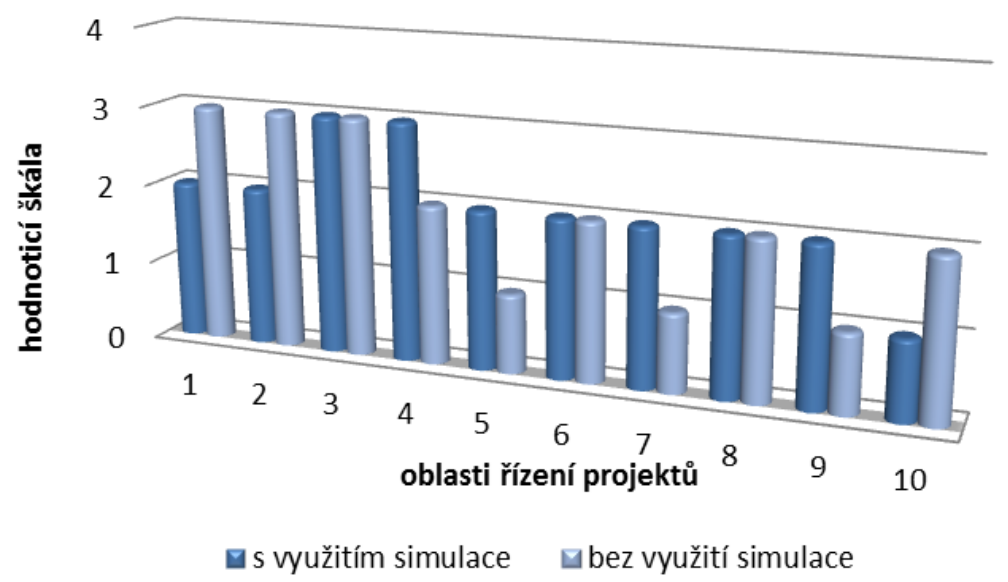

\section{Oblasti řízení výroby}

1- Doba trvání projektu

2- Dodržení rozpočtu projektu

3- Personální nároky

4- Shoda plán versus realita

5- Dodatečná využitelnost projektu

6- Flexibilita projektu na změny

7- Dědičnost projektu

8- Kvalita výstupních dat

9- Kvalita vstupních dat

10- Dopad na ostatní organizační složky

Zdroj: vlastní zpracování

Z hlediska organizování se rozdíl v hodnocení pohybuje maximálně v jednom stupni, přičemž zajímavé je např́klad pozastavit se nad vysokým hodnocením ovlivnění personálních nároků. Simulační projekty týkající se prímo personálních nároků na větší projekty mohou být zdrojem velmi cenných poznatků a šetření nemalých nákladů. 
Obrázek 4: Srovnání výsledků - přikazování

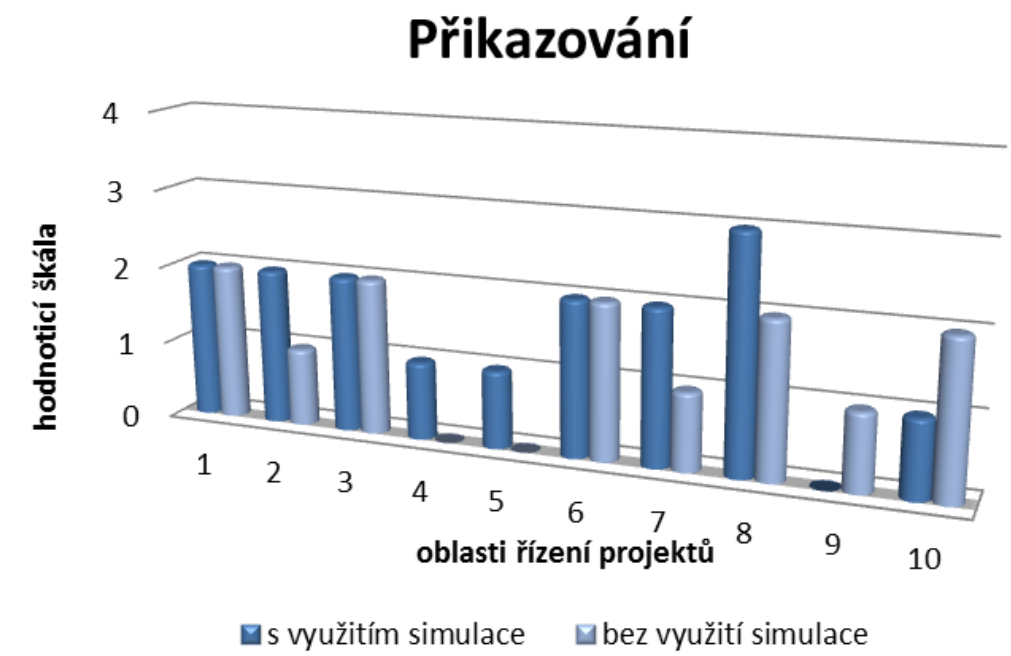

\section{Oblasti řízení výroby}

1- Doba trvání projektu

2- Dodržení rozpočtu projektu

3- Personální nároky

4- Shoda plán versus realita

5- Dodatečná využitelnost projektu

6- Flexibilita projektu na změny

7- Dědičnost projektu

8- Kvalita výstupních dat

9- Kvalita vstupních dat

10- Dopad na ostatní organizační složky

Zdroj: vlastní zpracování

Druhých nejnižších hodnot bylo dosaženo při hodnocení jednotlivých oblastí v kontextu třetí manažerské funkce - přikazování. Kromě jednoho výkyvu v podobě ovlivnění kvality vstupních dat nebylo nikde dosaženo vyššího hodnocení, než „normální prrínos“.

Obrázek 5: Srovnání výsledků - koordinace

\section{Koordinace}

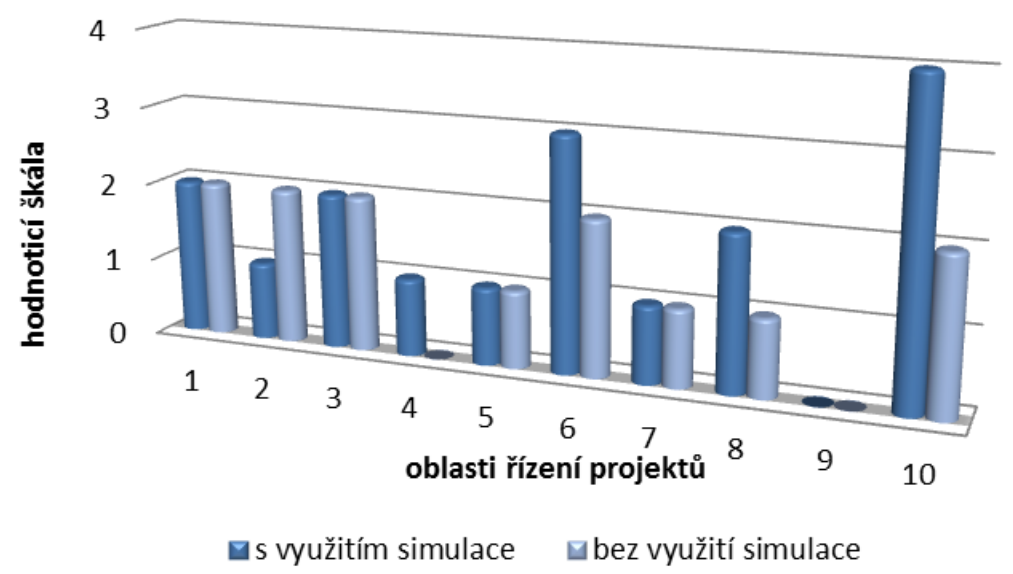

\section{Oblasti řízení výroby}

1- Doba trvání projektu

2- Dodržení rozpočtu projektu

3- Personální nároky

4- Shoda plán versus realita

5- Dodatečná využitelnost projektu

6- Flexibilita projektu na změny

7- Dědičnost projektu

8- Kvalita výstupních dat

9- Kvalita vstupních dat

10- Dopad na ostatní organizační složky

Zdroj: vlastní zpracování

Zejména poslední, desátý bod z pohledu koordinace s podporou simulací je velmi zajímavý. Simulační modely totiž umožňují podívat se na problém $\mathrm{z}$ mnoha různých úhlů pohledu a díky stále dokonalejší možnosti grafického zpracování a vizualizace napomáhají rychlému chápání problémů v širším kontextu, můžeme říci, že napomáhají systémově př́istupovat $\mathrm{k}$ řešení daného problému. 
Obrázek 6: Srovnání výsledků - kontrola

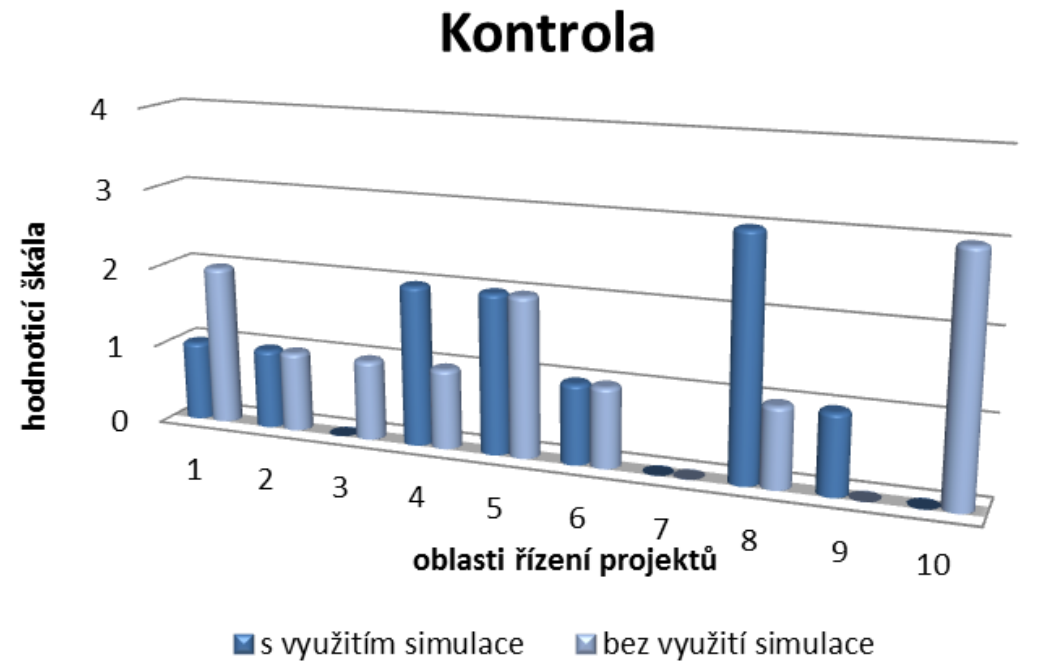

\section{Oblasti řízení výroby}

1- Doba trvání projektu

2- Dodržení rozpočtu projektu

3- Personální nároky

4- Shoda plán versus realita

5- Dodatečná využitelnost projektu

6- Flexibilita projektu na změny

7- Dědičnost projektu

8- Kvalita výstupních dat

9- Kvalita vstupních dat

10- Dopad na ostatní organizační složky

Zdroj: vlastní zpracování

Ačkoli se oba manažeři shodli, že v celkovém pohledu mají diskrétní simulace nejnižší př́nos právě při kontrole, rozcházejí se přesto velmi významně ve vnímání prŕnosu při zjištování dopadu na ostatní organizační složky. Tato skutečnost ale může být ovlivněna nejen vnímáním samotného př́ínosu diskrétní simulace, nýbrž také konkrétním firemním prostředím a kulturou.

\section{Závěr}

Z pohledu literárních zdrojů čerpá článek z odborné literatury a odborných článků z českého a anglosaského prostř̌edí. Předkládá náhled na diskrétní simulace $\mathrm{z}$ trochu netradičního úhlu pohledu, a to očima dvou manažerů - jednoho uživatele, druhého potenciálního uživatele. Srovnává pohled na užitečnost simulací od člověka, který je používá, a člověka, který je doposud pro podporu rozhodování nevyužil. V průběhu jednotlivých rozhovorů bylo velmi př́nosné sledovat postřehy a názory obou manažerů, jejich argumenty pro nebo naopak proti použití diskrétních simulací $\mathrm{v}$ daném prrípadě. Všechny tyto podnětné rozhovory nás velmi obohatili, a jelikož jsme si vědomi úzkého zaměření tohoto článku, budeme se tématu věnovat nadále a za pomoci jak kvalitativního, tak kvantitativního výzkumu se pokusíme zodpovědět další otázky, které během této studie vypluly napovrch a dosud zůstaly nezodpovězeny.

\section{Poděkování}

Rádi bychom v závěru poděkovali zejména manažerům dvou sledovaných firem za jejich obětovaný čas i ochotu spolupracovat. Dále pak především kolegům, kteří ochotně poskytli pomoc či radu.

\section{Literatura}

[1] FOTR, J., L. ŠVECOVÁ a kol., 2006. Manažerské rozhodování: postupy, metody a nástroje. Vyd. 1. Praha: Ekopress. ISBN 80-869-2915-9.

[2] HENDL, J., 2008. Kvalitativní výzkum: základní teorie, metody a aplikace. 2. aktualiz. vyd. Praha: Portál. ISBN 978-80-7367-485-4.

[3] HICKSON, D. J. a D. S. PUGH, 2008. Writers on organizations: základní teorie, metody a aplikace. 6th ed. London: Penguin, xv, 511 p. ISBN 978-014-1029-924. 
[4] HILL, C. W. a S. L. MCSHANE, 2008. Principles of management: základní teorie, metody a aplikace. 5th ed. Boston: McGraw-Hill/Irwin. ISBN 00-733-4133-9.

[5] JAHANGIRIAN, M., T. ELDABI, A. NASEER, L. K. STERGIOULAS a T. YOUNG, 2010. Simulation in manufacturing and business: A review. European Journal of Operational Research [online]. 203(1), 1-13 [cit. 2013-10-23]. DOI: 10.1016/j.ejor.2009.06.004.

[6] MCLEAN, J., 2011. Fayol - Standing the test of time. Manager: British Journal of Administrative Management [online]. Spring 2011, issue 74, s. 32 [cit. 2013-10-15]. ISSN 1353-5188.

[7] MITROFF, I. I., 2008. Knowing: how we know is as important as what we know. Journal of Business Strategy [online]. 29(3), 13-22 [cit. 2013-10-24]. DOI: 10.1108/02756660810873173.

[8] MOHELSKÁ, H. a Z. PITRA, 2012. Manažerské metody. 1. vyd. Praha: Professional Publishing. ISBN 978-80-7431-092-8.

[9] PROCHÁZKOVÁ, D., 2008. Př́padová studie a metodika pro její sestavení. Praha: Ministerstvo vnitra, Generální ředitelství Hasičského záchranného sboru ČR, s. 112, Roč. 7, č. 7, príloha. ISSN 1213-7057.

[10] RAUSCH, E., 2005. A practical focus on leadership in management - for research, education and management development. Management Decision [online]. 43(7/8), 9881000 [cit. 2013-10-16]. DOI: 10.1108/00251740510609983.

[11] REES, W. D., 2008. The skills of management: základni teorie, metody a aplikace. 5th ed. London [u.a.]: Thomson Learning. ISBN 978-186-1525-505.

[12] SWEETSER, A., 1999. A comparison of system dynamics and discrete event simulation. In: Proceedings of 17th International Conference of the System Dynamics Society and 5th Australian \& New Zealand Systems Conference. Wellington, New Zealand.

[13] SKOOGH, A., T. PERERA a B. JOHANSSON, 2012. Input data management in simulation - Industrial practices and future trends. Simulation Modelling Practice and Theory [online]. 29, 181-192 [cit. 2013-10-24]. DOI: 10.1016/j.simpat.2012.07.009.

[14] TAKO, A. A. a S. ROBINSON, 2012. The application of discrete event simulation and system dynamics in the logistics and supply chain context. Decision Support Systems [online]. 52(4), 802-815 [cit. 2013-10-22]. DOI: 10.1016/j.dss.2011.11.015.

[15] WOHLGEMUTH, V., B. PAGE a W. KREUTZER, 2006. Combining discrete event simulation and material flow analysis in a component-based approach to industrial environmental protection. Environmental Modelling [online]. 21(11), 1607-1617 [cit. 2013-10-22]. DOI: 10.1016/j.envsoft.2006.05.015. 